\title{
Oribatid communities and heavy metal bioaccumulation in selected species associated with lichens in a heavily contaminated habitat
}

\author{
Piotr Skubala $^{1} \cdot$ Kaja Rola $^{2} \cdot$ Piotr Osyczka $^{3}$ \\ Received: 27 April 2015 / Accepted: 11 January 2016/Published online: 26 January 2016 \\ (C) The Author(s) 2016. This article is published with open access at Springerlink.com
}

\begin{abstract}
The study examines oribatid communities and heavy metal bioaccumulation in selected species associated with different microhabitats of a post-smelting dump, i.e. three lichen species of Cladonia with various growth forms and the slag substrate. The abundance of oribatids collected from the substrate was significantly lower than observed in lichen thalli. The morphology and chemical properties of lichens, and to some extent varying concentrations of heavy metals in thalli, are probably responsible for significant differences in oribatid communities inhabiting different Cladonia species. Some oribatids demonstrate the ability to accumulate zinc and cadmium with unusual efficiency, whereas lead is the most effectively regulated element by all species. A positive correlation was found between $\mathrm{Zn}$ content in all studied oribatids and their microhabitats. Oribatids exploring different food resources, i.e. fungivorous and non-fungivorous grazers, show
\end{abstract}

Responsible editor: Philippe Garrigues

Electronic supplementary material The online version of this article (doi:10.1007/s11356-016-6100-z) contains supplementary material, which is available to authorized users.

Piotr Skubała

piotr.skubala@us.edu.pl

1 Department of Ecology, Faculty of Biology and Environmental Protection, University of Silesia, Bankowa 9, PL-40-007 Katowice, Poland

2 Department of Plant Taxonomy, Phytogeography and Herbarium, Institute of Botany, Jagiellonian University, Kopernika 27, PL-31-501 Kraków, Poland

3 Department of Polar Research and Documentation, Institute of Botany, Jagiellonian University, Kopernika 27, PL-31-501 Kraków, Poland considerable differences in bioconcentrations of certain elements.

Keywords Oribatid mites $\cdot$ Cladonia $\cdot$ Accumulation capacity $\cdot$ Zinc $\cdot$ Lead $\cdot$ Cadmium $\cdot$ Post-smelting wastes

\section{Introduction}

Smelting activities are of major concern in terms of metallic pollution in industrial regions. The smelting of metal ores, especially using the primitive technology of the past, has resulted in large quantities of wastes deposited as slag dumps, which are entirely artificial. Discarded wastes contain high concentrations of heavy metals, posing a threat to the local environment (Tyszka et al. 2014). The development of vegetation and fauna on heavy-metal-contaminated sites is extremely difficult due to the unfavourable physical and chemical properties of the substrate, as well as the limited pool of species capable of colonising them (Tordoff et al. 2000). Such severe habitat conditions lead to the emergence of ecosystems with a specific species composition.

Lichens (lichenised fungi) are known as stress-tolerators (Grime 1979), and some of them are well-adapted to metal contamination (Purvis and Halls 1996). Therefore, in many heavy-metal-polluted sites, assemblages of lichens constitute the main visual component of vegetation (Cuny et al. 2004; Rola and Osyczka 2014; Rola et al. 2015). The representatives of the lichen genus Cladonia are generally known for their morphological dimorphism: first they produce a primary thallus and then variously formed fruticose secondary thalli, called podetia. Due to their fruticose nature and relatively high biomass, some Cladonia species appear to be essential and effective rapid colonisers of bare substrates, including 
extremely contaminated slag dumps (Osyczka and Rola 2013a; Rola et al. 2014).

Many oribatid mites use lichens as a shelter and/or for feeding purposes. Some of them are examples of specialised lichen feeders (Erdmann et al. 2007; Fischer et al. 2010; Seyd and Seaward 1984). Oribatid mites are listed among those animals which exert a grazing impact on lichens (Seyd and Seaward 1984). However, Gjelstrup and Søchting (1979) observed that a lichen, as a whole, apparently does not suffer from the presence of the mite to any appreciable extent. In general, mites are engaged in mutual symbiosis involving all three organisms in the association, i.e. alga, fungus and mite (Gjelstrup and Søchting 1979). Seyd and Seaward (1984) found 83 oribatids in lichens and proposed a detailed classification system based on affinity. Lichens produce many specific secondary metabolites (Huneck and Yoshimura 1996). Seyd and Seaward (1984) reported that no particular lichen substances were repellent to oribatids. However, the toxic relevance of lichen secondary compounds to invertebrates remains controversial. Many studies have shown a defensive role for lichen substances, which may help to protect thalli against herbivores (e.g. Asplund and Gauslaa 2007, 2008; Gauslaa 2005; Pöykkö et al. 2005).

Due to high levels of contamination, the development rate of oribatid fauna is retarded in contaminated dumps (Skubała et al. 2014). Among soil mites, oribatids in particular are able to accumulate metals to very high internal concentrations (Roth 1993; van Straalen and van Wensem 1986). More is becoming known about heavy-metal tolerance, storage and elimination in oribatid mites. For example, the precipitation of metals as intracellular electron-dense granules (EDGs) has been observed in the digestive epithelia of oribatid mites (Alberti et al. 2003; Ludwig et al. 1992). Since some oribatid mites, as edaphic animals, feed on 'metal-enriched' fungal mycelia (Roth 1992), they are particularly suited for study of the concentrations of heavy metals.

Although oribatid communities on lichens have been studied by several authors (e.g. Behan-Pelletier and Walter 2000; Erdmann et al. 2006; Fischer et al. 2010; Materna 2000; Seyd and Seaward 1984), the knowledge about these associations in highly contaminated habitats is limited (see Skubała et al. 2014). To recognise the role of lichens in establishing oribatid mite communities, we compared the oribatid fauna associated with three Cladonia lichen species and the corresponding substrate derived from slag dumps. Furthermore, to assess the pattern of heavy metal accumulation in the body of oribatids dwelling in different microhabitats (Cladonia thalli and dump's substrate), we analysed metal body burdens in selected oribatid species. More specifically, we addressed the following hypotheses:

- Lichen thalli constitute a less contaminated microhabitat and therefore are populated by richer oribatid fauna than that found on the surrounding slag substrate.
- Oribatid fauna does not differ significantly among various Cladonia species.

- The burdens of zinc, lead and cadmium in the body of oribatid mites depend on the contents of these metals in their microhabitats.

- Nutritional metals are accumulated differently than xenobiotics in the bodies of oribatid species.

- Oribatid species feeding mainly on fungi are characterised by higher body burdens of heavy metals.

\section{Materials and Methods}

\section{Study area and microhabitat description}

The study was performed on a post-smelting dump located in the town of Piekary Śląkie (centre of the dump: $55^{\circ} 21^{\prime} 11^{\prime \prime} \mathrm{N}$, $18^{\circ} 58^{\prime} 00^{\prime \prime} \mathrm{E}$; c. $255,000 \mathrm{~m}^{2}$ ) within the Upper Silesian Industrial Region. The slag dump was deposited as a result of the processing of $\mathrm{Zn}-\mathrm{Pb}$ ores and consists entirely of artificial slag wastes, which have weathered into a form of friable substrate and partially moulding sinters (Tyszka et al. 2014). Thirty years have elapsed since tipping ceased on this site which is still characterised by unfavourable habitat conditions (Skubała 2011). The average content of organic carbon is low (1.47\%), as is that of total nitrogen $(0.08 \%)$; the same is true of the concentrations of macronutrient elements (see dump D2: Osyczka and Rola 2013a). The vegetation on most of the slag dump is characterised by a large proportion of cryptogams, with Cladonia spp. clearly predominating (Osyczka and Rola 2013a).

Lichens, and the slag substrate under lichen vegetation, were considered as microhabitats for oribatid mites in this study. Three species of Cladonia, representing different growth forms of podetia and producing different types of propagules, were selected: Cladonia cariosa (Ach.) Spreng., Cladonia pyxidata (L.) Hoffm. and Cladonia rei Schaer. (Fig. S1). All three are effective colonisers of post-smelting dumps (Osyczka and Rola 2013a; Rola et al. 2014). Cladonia cariosa has torn and fissured podetia, often sparingly branched above, with areolate surfaces and/or surfaces covered with numerous corticated granules. Cladonia pyxidata forms typically cup-shaped podetia; the interiors and exteriors of the cups are covered with coarse, corticated granules and/or sparse squamules. The last-mentioned species is generally characterised by long and contorted podetia with partially corticated surfaces densely covered by farinose to granular soredia and squamules which develop to various degrees. Some individuals of Cladonia rei are referred to a specific 'robust/squat' morphotype of this species described from slag dumps (Osyczka et al. 2014). 


\section{Field studies and sampling}

A study plot representing a single stage of succession with a homogenous patch of cryptogamic vegetation was established on the dump. Ten samples of Cladonia cariosa, Cladonia pyxidata and Cladonia rei were randomly collected along with the corresponding substrate to a depth of $5 \mathrm{~cm}$. The lichens (10-20 g) were carefully detached from the surface and packed into zip-lock polythene bags. Substrate samples (40-60 g) were collected using a stainless steel corer. Sampling was done in 2012 during a dry spring season under similar conditions (between 9 and 11 a.m. in sunny weather).

Animals were extracted from samples (lichens and substrate) by means of a Berlese-Tullgren apparatus. Adult individuals and juveniles of Tectocepheus velatus were identified after Weigmann (2006); nomenclature follows Subias (2004). Lichen specimens were determined using stereoscopic and light microscopes; chemical analyses of lichen secondary substances were performed by means of thin-layer chromatography (TLC), following Orange et al. (2001). Lichen and substrate samples were dried and weighed, and numbers of mites per $100 \mathrm{~g}$ dry weight (DW) were calculated.

\section{Analysis of substrate and lichen samples}

Three samples each of Cladonia cariosa, Cladonia pyxidata and Cladonia rei thalli and three samples of associated substrate were designated for chemical analyses. Macroscopic foreign materials adhering to the thalli surfaces were removed; samples were then rinsed with deionised water, dried at $90{ }^{\circ} \mathrm{C}$ for c. $24 \mathrm{~h}$ to a constant weight and ground into powder. Concentrations of $\mathrm{Zn}, \mathrm{Pb}$ and $\mathrm{Cd}$ were determined by means of atomic absorption spectrometry. All details concerning sample preparation and chemical analysis are described in Skubała et al. (2014).

\section{Test species and analytical methods}

Five species, i.e. Ceratozetes mediocris, Liochthonius lapponicus, Oppiella nova nova, Oribatula tibialis tibialis, Tectocepheus velatus velatus, and juveniles of $T$. velatus were selected to study $\mathrm{Zn}, \mathrm{Pb}$ and $\mathrm{Cd}$ concentrations in their bodies and to investigate trends in accumulations of metals in oribatids collected from different Cladonia species and the dump's substrate. A group of 50 specimens were pooled and weighed three times to establish their weight accurately. Other details concerning analysis of metals in the bodies of oribatid species are described in Skubała et al. (2014).

The bioconcentration factor (BCF) was calculated according to the formula: concentration of the metal in the organism/ concentration of the metal in the microhabitat. BCF is a parameter used to describe the transfer of trace elements from the soil to oribatid bodies. We used the term 'accumulator' for species with a $\mathrm{BCF} \geq 1$, and 'non-accumulator' or 'deconcentrator' for oribatids characterised by a $\mathrm{BCF}<1$.

\section{Statistical analysis}

Four univariate measures were used to assess oribatid community structure: abundance per $100 \mathrm{~g} \mathrm{DW}$, total and mean number of species, and the Shannon index $\left(\log _{2}\right)$. One-way analysis of variance (ANOVA) was performed, followed by Tukey's HSD test, to reveal significant differences in oribatid fauna between the four microhabitats under consideration (three Cladonia lichens and the dump's substrate). Variables deviating from a normal distribution (Kolmogorov-Smirnov test with Lilliefors correction) were transformed using natural logarithms. Significant effects of microhabitat type and oribatid species on particular element concentrations in the bodies of oribatids were calculated by means of multivariate analysis of variance (MANOVA) using Wilks's lambda test statistic. When the result of MANOVA was significant $(p<0.05)$, univariate tests for each element and Tukey's HSD post-hoc tests were performed to detect significant differences between particular species and microhabitat types. Additionally, differences between heavy-metal contents in juvenile and adult forms of T. velatus were verified by Student's $t$ test.

The interrelationships between concentrations of heavy metals in the bodies of selected oribatid species and content of metals in the corresponding thalli of particular Cladonia species and the dump's substrate were checked using the Pearson correlation coefficient.

A DCA was carried out to determine if the species matrix exhibited a linear or a unimodal response. According to ter Braak and Šmilauer (2002), if the length of the gradient for the first axis is less than 3, the data display a linear response. As the length of gradient equalled 1.057, principal component analysis (PCA) was chosen for the ordination analysis and was applied to the $\log (x+1)$-transformed original abundance data to test for differences in oribatid community structure between microhabitats. Singletons were removed from the analysis.

Statistical calculations were performed using STATISTICA 10 and CANOCO v 4.5 for Windows.

\section{Results}

\section{Microhabitat conditions}

As regards the dump's substrate, the amounts of $\mathrm{Zn}, \mathrm{Pb}$ and $\mathrm{Cd}$ exceeded maximum concentrations for uncontaminated soils by factors of 14, 10 and 5, respectively (cf. KabataPendias and Pendias 2001 and Fig. 1). Amounts of heavy metals in Cladonia thalli were lower than in the dump's substrate. Only the content of $\mathrm{Pb}$ in Cladonia rei was slightly 
higher than in the substrate. Generally, different Cladonia species accumulated heavy metals at similar levels. However, Cladonia rei seems to be a somewhat stronger accumulator of $\mathrm{Zn}$ and $\mathrm{Pb}$, whereas Cladonia pyxidata absorbed slightly more Cd (Fig. 1).

\section{Abundance of oribatid mites across microhabitats}

In total, 6081 mesofauna specimens were collected, of which 5140 individuals belonged to the Acari taxon, with a significant proportion of oribatid mites (3014 specimens). Most oribatids (59\%) were collected from lichen thalli. The abundance of oribatids collected from the dump's substrate (5.7 individuals $100 \mathrm{~g}^{-1} \mathrm{DW}$ ) was much lower than in lichen thalli. Among the examined lichen thalli, Cladonia pyxidata contained the highest average number of oribatid mites (220.7 indiv. $100 \mathrm{~g}^{-1} \mathrm{DW}$ ) and Cladonia cariosa the lowest (25.0 indiv. $\left.100 \mathrm{~g}^{-1} \mathrm{DW}\right)$. The number of adult specimens was two (Cladonia pyxidata) to four times (Cladonia cariosa) higher than juveniles (Table 1). ANOVA revealed significant differences in the abundance of juvenile and adult oribatids among studied microhabitats (Table 1). The proportion of Oribatida relative to the total number of Acari was highest in Cladonia rei thalli (71.4\%), while maintaining similar levels in Cladonia pyxidata (52.2\%), Cladonia cariosa $(50 \%)$ and the dump's substrate $(59.2 \%)$.

\section{Species richness patterns and species composition}

Forty-five species of oribatid mites belonging to 31 genera were identified (see Appendix). Differences in species richness between microhabitats were also pronounced. The highest number of species was recorded in Cladonia rei thalli (38). The number of oribatid species associated with Cladonia pyxidata thalli (16) and
Cladonia cariosa thalli (8) was much lower, whereas 21 species were recorded in the dump's substrate. Similarly, the mean number of species was the highest on Cladonia rei thalli (10.2) and the lowest on Cladonia cariosa thalli (3.5). Significant differences in species richness between particular microhabitats were observed. The Shannon index, generally low for all microhabitats, was the highest in Cladonia rei thalli and the lowest in Cladonia cariosa thalli (Table 1).

As many as 26 species (58 \% of the total number of species) were restricted to one microhabitat (see Appendix). Twenty species occurred exclusively in Cladonia rei thalli; however, only $L$. propinquus constituted a substantial part of the mite fauna $(12.5 \%)$. Five species were specific to the dump's substrate, with Punctoribates punctum being the most numerous $(6.3 \%)$. Six species were common to all microhabitats. $T$. velatus reached a disproportionally high percentage in the total abundance of oribatids (over $50 \%$ ) over all studied microsites.

The PCA ordination diagram distinguished four different groups of oribatids (Fig. 2). The first axis $(72.1 \%$ of the total variance) distinguished between oribatid fauna characteristic of Cladonia pyxidata and Cladonia rei thalli (right part of the diagram) and other microhabitats (left part). The second axis (21.5\% of the total variance) separated Cladonia rei thalli (upper part of axis 2) from Cladonia pyxidata thalli (lower part of axis 2). At least three oribatid species can be considered as being associated with Cladonia pyxidata thalli, namely Ceratozetes mediocris, Oribatula tibialis and Suctobelbella (Flagrosuctobelba) alloenasuta. The highest number of species was recorded in Cladonia rei thalli; however, only L. propinquus was strongly associated with this microhabitat. Suctobelbella acutidens sarekensis was typical for Cladonia cariosa thalli, whereas P. punctum was unique for the dump's substrate.
Fig. 1 Concentrations of particular metal elements across all microhabitats $(n=3)$. Bars indicate mean values; whiskers show minimum and maximum values. Abbreviations as follow: CAR - Cladonia cariosa, PYXCladonia pyxidata, REICladonia rei, SUBS - dump's substrate

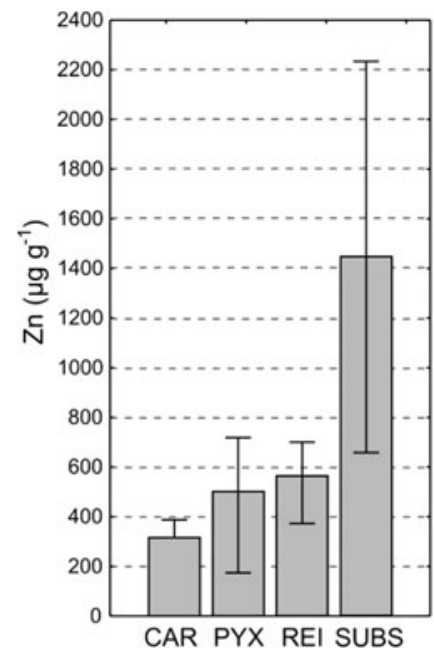

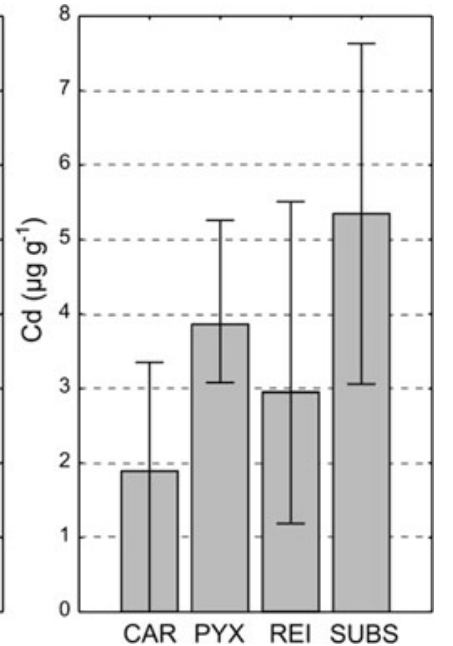


Table 1 Diversity of oribatid mites collected from Cladonia species and the associated substrate at the post-smelting dump: abundance (indiv. $100 \mathrm{~g}^{-1} \mathrm{DW} \pm$ S.E.), species richness (mean \pm S.E.), Shannon diversity $\left(H^{\prime}\right)$ and ANOVA results $(p=0.05)$ for the hypothesis of no effect of microhabitat. Values with identical letters within the same row are not significantly different to each other at the $p<0.05$ level according to the Tukey's HSD test. The highest values of selected characteristics are given in italics

\begin{tabular}{|c|c|c|c|c|c|c|}
\hline \multirow[b]{2}{*}{ Diversity parameters } & \multicolumn{4}{|l|}{ Microhabitats } & \multicolumn{2}{|c|}{ ANOVA } \\
\hline & Cladonia cariosa & Cladonia pyxidata & Cladonia rei & Substrate & $F$ & $p$ \\
\hline Oribatida adults & $20.5 \pm 6.6 \mathrm{ab}$ & $152.1 \pm 43.9 c$ & $72.4 \pm 12.1 \mathrm{~b}$ & $3.1 \pm 0.6 \mathrm{a}$ & 17.714 & 0.000 \\
\hline Oribatida juveniles & $4.5 \pm 1.5 \mathrm{a}$ & $68.6 \pm 19.3 b$ & $23.4 \pm 4.4 \mathrm{a}$ & $2.7 \pm 0.6 \mathrm{a}$ & 18.054 & 0.000 \\
\hline Oribatida total & $25.0 \pm 7.9 \mathrm{a}$ & $220.7 \pm 62.2 b$ & $95.8 \pm 16.0 \mathrm{a}$ & $5.7 \pm 1.1 \mathrm{a}$ & 18.384 & 0.000 \\
\hline Total number of species & 8 & 16 & 38 & 21 & - & - \\
\hline Mean number of species & $3.5 \pm 0.4 \mathrm{a}$ & $7.0 \pm 0.7 \mathrm{ab}$ & $10.2 \pm 1.7 b$ & $4.8 \pm 0.8 \mathrm{a}$ & 6.894 & 0.000 \\
\hline $\mathrm{H}^{\prime}$ & $0.487 \pm 0.1 \mathrm{a}$ & $1.381 \pm 0.1 \mathrm{~b}$ & $1.400 \pm 0.2 b$ & $0.887 \pm 0.1 \mathrm{ab}$ & 5.445 & 0.002 \\
\hline
\end{tabular}

\section{Heavy-metal burdens in oribatid species}

Oribatid species have different accumulation capacities for certain heavy metals (Table 2). MANOVA revealed highly significant differences in concentrations of metal elements in the bodies of oribatids with regard to oribatid species and microhabitat type (Wilks's lambda $=0.003$ and 0.105 , respectively). The highest concentrations of $\mathrm{Zn}$ were found in Ceratozetes mediocris, T. velatus and Oribatula tibialis. The concentrations of $\mathrm{Zn}$ in the smallest species among those studied (L. lapponicus and Oppiella nova) were considerably lower. Even though the concentrations of $\mathrm{Zn}$ in juvenile forms of T. velatus varied greatly, adult individuals accumulated significantly higher amounts of $\mathrm{Zn}$ than juveniles $(t=6.90$; $p<0.001)$. In general, the amount of $\mathrm{Zn}$ in most oribatid species (except Oribatula tibialis) collected from the substrate was significantly higher than in individuals collected from lichens (Table 2). As regards $\mathrm{Pb}$, the highest average concentrations were found in Ceratozetes mediocris, Oppiella nova and juvenile forms of $T$. velatus, whereas the lowest were found in L. lapponicus and Oribatula tibialis. The best accumulator of $\mathrm{Cd}$ was Ceratozetes mediocris; the concentration of the metal in this species was four to ten times higher than in other species. Oppiella nova and Oribatula tibialis were characterised by the lowest concentrations of $\mathrm{Cd}$. In general, the levels of $\mathrm{Cd}$ and $\mathrm{Pb}$ recorded in oribatids collected from the substrate were higher than in individuals collected from lichens (Table 2).

The calculated values of BCF are presented in Table 2. The noticeable $\mathrm{Zn}$ enrichment was found for two oribatid mites, Ceratozetes mediocris and adult forms of T. velatus (Table 2). Although lichen thalli and the dump's substrate were seriously
Fig. 2 The biplot of the first two axes of the principal component analysis (PCA) of the four microhabitats at the post-smelting dump. Species that constituted more than $2.1 \%$ of the total number are presented in a frame. Abbreviations of the species, see Appendix

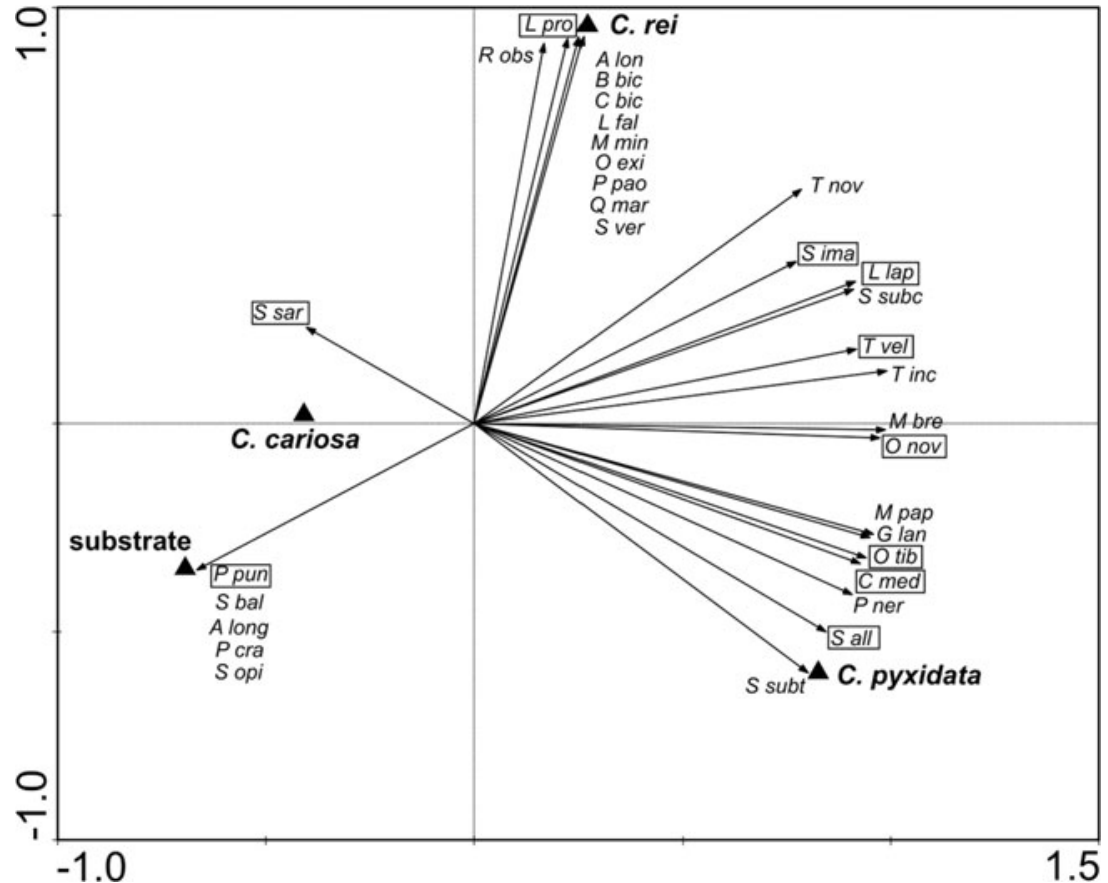


contaminated with $\mathrm{Pb}$, oribatid species were not enriched with the metal, as the concentrations of $\mathrm{Pb}$ in the bodies of oribatids were much lower relative to those recorded in their microhabitats. Ceratozetes mediocris also appears to be an accumulator of $\mathrm{Cd}$, with BCF varying from 1.5 in Cladonia rei to 4.4 in Cladonia cariosa. In contrast, other oribatid species can be described as deconcentrators of this metal; however, the value of BCF for all species was not as low as in the case of $\mathrm{Pb}$. The bioconcentration factor differs slightly between studied microhabitats; however, it was not possible to find a general rule (Table 2).

A significant positive correlation was found between the contents of $\mathrm{Zn}$ in the bodies of oribatid species and corresponding microhabitats in the case of all studied species. A negative or very low positive correlation was recorded for $\mathrm{Cd}$. As regards $\mathrm{Pb}$, negative correlations (Oribatula tibialis, Oppiella nova) or slightly positive correlations (other species) were detected (Table 3).

\section{Discussion}

\section{Zoocoenotic characteristics of oribatid fauna in Cladonia species and the dump's substrate}

The number of species recorded on lichens was twice that in the dump's substrate and oribatid mite abundance was 4 times (Cladonia cariosa) to over 35 times (Cladonia rei) higher on thalli than in the corresponding substrate. The comparatively high number of oribatid species in the thallus of lichens is probably due to invasion by soil-inhabiting oribatids. This indicates that lichens constitute a specific habitat which, isolated from the direct influences of the surrounding substrate, seems more suitable for oribatid mites.

A clear preference for lichen thalli over the surrounding substrate by oribatid mites at the dump is similar to a phenomenon observed in corticolous arthropods on tree trunks. The minute structures of lichen thalli positively influence the abundance and living conditions of various arthropods occurring on the bark (Prinzing and Wirtz 1997). Lichen thalli might protect against excessive solar radiation, wind and desiccation. The benefits are mutual, as oribatid mites play an important role in the dispersal of lichen spores and propagules by transporting them on body surfaces or in the gut (Gerson and Seaward 1977; Root et al. 2007; Seyd and Seaward 1984; Stubbs 1995).

Cladonia lichens proved to be rather weak accumulators; heavy-metal concentrations in their thalli are considerably lower than in the host substrate (Osyczka and Rola 2013b). Consequently, it can be concluded that oribatid mites choose these lichens not only as a shelter or source of food but also as less-contaminated microhabitats. This phenomenon supports the idea that oribatid mites resist heavy metals by selecting less-contaminated microsites (Bengtsson et al. 1994; Skubała et al. 2014; Tranvik and Eijsackers 1989). Furthermore, since the oribatids are sensitive to disturbances caused by enchytraeids and earthworms, they may take advantage of increased space and resources due to the scarcity of those metal-sensitive organisms (Creamer et al. 2008; Maraun and Scheu 2000; Maraun et al. 2003).

Oribatid communities differed not only between lichens and the dump's substrate but also among different species of Cladonia. A significantly higher abundance of oribatids was recorded on the thalli of Cladonia pyxidata in comparison with two other lichens, whereas the highest total and mean number of species were recorded on Cladonia rei. The observed differences in the oribatid fauna are probably due to the various morphological structures of lichen thalli. Colloff (1988) remarked that thallus morphology has a definite influence on oribatid species diversity. Both species richness and abundance of oribatids may depend on the growth form of lichens (Fröberg et al. 2003; Root et al. 2007; Smrž and Kocourková 1999). All of the Cladonia species considered in this study are fruticose; however, they apparently differ in micromophological structure. Cladonia rei demonstrates great variability in the growth forms of its podetia, which are richly covered with various propagules, such as corticated granules, squamules and microsquamules as well as numerous noncorticated, farinose-to-granular soredia (see Dolnik et al. 2010; Osyczka et al. 2014). Therefore, Cladonia rei has a greater surface area/volume ratio in comparison to other studied Cladonia species. This species provides more microniches for tiny oribatid mites and for gathering of the organic matter particles which constitute their nourishment. In contrast, the morphology of Cladonia cariosa and Cladonia pyxidata is less diversified; their podetia do not produce soredia (see James 2009). Consequently, the huge morphological variability of Cladonia rei could be the main reason it is characterised by the highest diversity of oribatids among examined species. Another important factor affecting oribatid communities on lichens may be associated with the production of secondary metabolites by mycobionts. Some of these compounds have been shown to exhibit activity which is toxic and antifeedant to invertebrates (see Huneck 1999; Molnár and Farkas 2010). The low levels of diversity and abundance of oribatids on the thalli of Cladonia cariosa could be connected with the storage of atranorin in its cortex (Reutimann and Scheidegger 1987), which has been shown to be a deterrent to herbivory and to exhibit toxic effects on some invertebrates (Nimis and Skert 2006; Pöykkö et al. 2005; Slansky 1979). Cladonia pyxidata produces fumarprotocetraric acid, which also exerts an adverse effect on invertebrates and may help to protect the thalli against herbivores (Hesbacher et al. 1995). However, the abundance of oribatids was much higher on the thalli of Cladonia pyxidata than on other species. Fumarprotocetraric acid in Cladonia 
Table 2 Heavy metal concentrations ( $\mu \mathrm{g} / \mathrm{g}$ of fresh weight; mean \pm S.E., $n=3$ ) in the oribatids' bodies and mean bioconcentration factors (BCF, in parentheses) of oribatid species collected from three Cladonia species and the substrate on the post-smelting dump. The highest concentrations of particular heavy metals and $\mathrm{BCF} \geq 1.0$ are given in italics. Mean values with identical letters within the same row are not significantly different to each other at the $p<0.05$ level according to the Tukey's HSD test

\begin{tabular}{|c|c|c|c|c|c|c|c|}
\hline \multirow[t]{2}{*}{ Element } & \multirow[t]{2}{*}{ Microhabitat } & \multicolumn{6}{|l|}{ Oribatid species } \\
\hline & & $\begin{array}{l}\text { Ceratozetes } \\
\text { mediocris }\end{array}$ & $\begin{array}{l}\text { Liochthonius } \\
\text { lapponicus }\end{array}$ & Oppiella nova & $\begin{array}{l}\text { Oribatula } \\
\text { tibilias }\end{array}$ & $\begin{array}{l}\text { Tectocepheus } \\
\text { velatus }\end{array}$ & $\begin{array}{l}\text { Tectocepheus } \\
\text { velatus (juv.) }\end{array}$ \\
\hline \multirow{4}{*}{$\mathrm{Zn}$} & CAR & $1120.0 \pm 111.7 b(3.5)$ & $3.2 \pm 0.4 \mathrm{a}(0.01)$ & $35.5 \pm 1.8 \mathrm{a}(0.1)$ & $260.0 \pm 29.8 \mathrm{a}(0.8)$ & $330.0 \pm 17.4 \mathrm{a}(1.1)$ & $2.1 \pm 0.1 \mathrm{a}(0.01)$ \\
\hline & PYX & $1724.7 \pm 512.4 b(3.4)$ & $23.5 \pm 3.1 \mathrm{a}(0.05)$ & $2.0 \pm 0.5 \mathrm{a}(0.004)$ & $426.4 \pm 27.3 \mathrm{a}(0.8)$ & $695.6 \pm 74.8 \mathrm{a}(1.4)$ & $260.2 \pm 72.9 \mathrm{a}(0.5)$ \\
\hline & REI & $772.6 \pm 220.6 b(1.4)$ & $21.5 \pm 1.6 \mathrm{ab}(0.04)$ & $58.6 \pm 12.2 \mathrm{ab}(0.1)$ & $197.2 \pm 17.7 \mathrm{ab}(0.3)$ & $432.5 \pm 22.7 \mathrm{ab}(0.8)$ & $2.0 \pm 0.5 \mathrm{a}(0.004)$ \\
\hline & SUBS & $1774.9 \pm 298.2 b(1.2)$ & $33.5 \pm 3.2 \mathrm{a}(0.02)$ & $476.0 \pm 96.1 \mathrm{a}(0.3)$ & $370.0 \pm 121.6 \mathrm{a}(0.2)$ & $1520.7 \pm 87.4 \mathrm{~b}(1.0)$ & $582.0 \pm 6.6 \mathrm{a}(0.4)$ \\
\hline \multirow[t]{4}{*}{$\mathrm{Pb}$} & CAR & $75.8 \pm 3.8 b(0.1)$ & $68.4 \pm 4.8 \mathrm{ab}(0.1)$ & $34.6 \pm 1.4 \mathrm{a}(0.07)$ & $28.2 \pm 2.3 \mathrm{a}(0.06)$ & $56.1 \pm 3.6 \mathrm{ab}(0.1)$ & $88.3 \pm 6.1 b(0.2)$ \\
\hline & PYX & $110.8 \pm 9.7 \mathrm{c}(0.4)$ & $12.6 \pm 0.7 \mathrm{a}(0.04)$ & $131.6 \pm 4.8 c(0.05)$ & $44.4 \pm 3.2 \mathrm{ab}(0.2)$ & $58.7 \pm 4.8 \mathrm{~b}(0.2)$ & $14.5 \pm 0.8 \mathrm{a}(0.05)$ \\
\hline & REI & $81.9 \pm 6.1 c(0.1)$ & $34.6 \pm 2.9 \mathrm{ab}(0.06)$ & $24.7 \pm 2.2 \mathrm{ab}(0.04)$ & $6.6 \pm 0.8 \mathrm{a}(0.01)$ & $53.8 \pm 14.9 \mathrm{bc}(0.09)$ & $38.3 \pm 1.6 \mathrm{ab}(0.06)$ \\
\hline & SUBS & $178.0 \pm 14.6 c(0.3)$ & $29.8 \pm 3.0 \mathrm{a}(0.06)$ & $127.8 \pm 12.5 \mathrm{~b}(0.2)$ & $11.6 \pm 1.7 \mathrm{a}(0.02)$ & $168.2 \pm 21.0 \mathrm{bc}(0.3)$ & $145.8 \pm 3.1 \mathrm{bc}(0.3)$ \\
\hline \multirow[t]{4}{*}{$\mathrm{Cd}$} & CAR & $8.35 \pm 0.5 b(4.4)$ & $0.77 \pm 0.8 \mathrm{a}(0.4)$ & $0.60 \pm 0.03 \mathrm{a}(0.3)$ & $0.72 \pm 0.04 \mathrm{a}(0.4)$ & $0.82 \pm 0.07 \mathrm{a}(0.4)$ & $1.71 \pm 0.2 \mathrm{a}(0.9)$ \\
\hline & PYX & $10.32 \pm 0.5 b(2.7)$ & $0.85 \pm 0.04 \mathrm{a}(0.2)$ & $0.83 \pm 0.08 \mathrm{a}(0.2)$ & $0.93 \pm 0.1 \mathrm{a}(0.2)$ & $1.32 \pm 0.1 \mathrm{a}(0.3)$ & $0.58 \pm 0.06 \mathrm{a}(0.1)$ \\
\hline & REI & $4.37 \pm 0.3 b(1.5)$ & $2.18 \pm 0.4 \mathrm{a}(0.7)$ & $0.75 \pm 0.1 \mathrm{a}(0.2)$ & $0.86 \pm 0.1 \mathrm{a}(0.3)$ & $0.90 \pm 0.1 \mathrm{a}(0.3)$ & $0.88 \pm 0.1 \mathrm{a}(0.3)$ \\
\hline & SUBS & $8.47 \pm 0.8 c(1.6)$ & $3.14 \pm 1.0 \mathrm{~b}(0.6)$ & $0.73 \pm 0.04 \mathrm{a}(0.1)$ & $0.89 \pm 0.01 \mathrm{a}(0.2)$ & $2.54 \pm 0.2 \mathrm{ab}(0.5)$ & $1.88 \pm 0.04 \mathrm{ab}(0.3)$ \\
\hline
\end{tabular}

Microhabitats: CAR Cladonia cariosa, PYX Cladonia pyxidata, REI Cladonia rei, SUBS substrate

pyxidata is confined exclusively to the medulla and appeared to be either lacking or negligible in the algal and cortical layers. Thus, oribatids feeding on Cladonia pyxidata could easily avoid the uptake of this lichen compound from the interior parts of thalli, as found in the feeding preferences of Eilema complana larvae (Hesbacher et al. 1995). Individuals of Cladonia rei examined in this study contained only homosekikaic acid, with no toxic effect determined to date. This may be an additional attribute of Cladonia rei as a suitable microhabitat for various oribatids. Furthermore, the high abundance of oribatids on Cladonia pyxidata could also be the result of relatively low concentrations of toxic $\mathrm{Pb}$ in the thalli (Fig. 1). However, with regard to $\mathrm{Zn}$ and $\mathrm{Cd}$, there was no clear relationship between content of metals and abundance or species richness of oribatids in the lichen thalli.

Some mites strongly prefer certain lichen species (Fröberg et al. 2003). In our study, according to the classification of Seyd and Seaward (1984), none of the recorded oribatids represent group A (species restricted to lichens as a biotope) or B (species preferring lichens as a habitat). Seven species could be classified within group $\mathrm{C}$, which includes oribatids frequently associated with lichens but equally common in other habitats (see Appendix). Nevertheless, the differences in oribatid composition among studied lichens are apparent; some oribatids proved to be strongly linked to particular Cladonia species (Fig. 2). Generally, oribatid species dwelling Cladonia lichens are exposed to similar source of food. Therefore, microhabitat properties (i.e. morphology of thallus, secondary metabolite production, content of heavy metals), not nutritional factors, are probably responsible for a mite's preferences (see also Gerson and Seaward 1977; Lawrey 1987).

\section{Bioaccumulation of heavy metals in oribatid species}

High interspecific variation in the concentrations of heavy metals has been observed in our study. Zinc is an essential element required in several key enzymes (Rainbow 1988; Taylor and Simkiss 1984); thus, one might expect that animals are able to regulate its internal concentrations at a more or less fixed level. This ability may differ among species due to varying storage or elimination capacities. Our results fit well with those of other authors who also observed a wide variation in Zn body burden in oribatids (Skubała and Kafel 2004; Skubała and Zaleski 2012; Zaitsev and van Straalen 2001).

Table 3 Pearson's correlation coefficients $(R)$ between the content of heavy metals in the bodies of selected oribatid species vs. content of metals in microhabitats (lichen thalli and substrate) at the post-smelting dump

\begin{tabular}{llcr}
\hline Oribatid species & $\mathrm{Zn}$ & $\mathrm{Pb}$ & $\mathrm{Cd}$ \\
\hline Ceratozetes mediocris & $0.63^{*}$ & 0.05 & 0.24 \\
Liochthonius lapponicus & $0.65^{*}$ & 0.21 & 0.17 \\
Oppiella nova & $0.90^{*}$ & -0.33 & 0.22 \\
Oribatula tibialis & $0.62^{*}$ & $-0.59^{*}$ & -0.04 \\
Tectocepheus velatus & $0.69^{*}$ & 0.14 & 0.37 \\
Tectocepheus velatus (juv.) & $0.64^{*}$ & 0.31 & -0.04 \\
\hline
\end{tabular}

*Significant at $p<0.05$ 
However, the ability of Ceratozetes mediocris to accumulate $\mathrm{Zn}$ in high quantities had not been documented so far. The species and adult forms of $T$. velatus appeared to be an accumulator of $\mathrm{Zn}$ irrespective of their microhabitats. Furthermore, besides Oppiella nova and Oribatula tibialis (analysed by Skubała and Kafel 2004 and Skubała and Zaleski 2012), L. lapponicus was found to be the deconcentrator of $\mathrm{Zn}$. The $\mathrm{Pb}$ accumulation capacity of oribatids is generally low; relatively comparable concentrations of this element were observed in the specimens. It seems that the investigated species are able to prevent high internal $\mathrm{Pb}$ concentrations, possibly due to low uptake through the gut wall or by rapid excretion of $\mathrm{Pb}$ (Janssen and Hogervorst 1993). Cd concentrations in the oribatid bodies are the lowest and the least variable, except for Ceratozetes mediocris, which turned out to be an accumulator of this metal. Other authors did not observed a general rule for $\mathrm{Cd}$ accumulation by oribatids (ElSharabasy and Ibrahim 2010; Janssen and Hogervorst 1993; Skubała and Kafel 2004; Skubała and Zaleski 2012; Zaitsev 1999).

L. lapponicus, Oppiella nova, Oribatula tibialis and juveniles of T. velatus can be categorised as non-accumulators of all studied heavy metals. Generally, Ceratozetes mediocris showed the highest burdens of $\mathrm{Zn}, \mathrm{Cd}$ and $\mathrm{Pb}$ irrespective of microhabitat (Table 2); thus, it can be clearly regarded as an accumulator of the first two heavy metals. Adults of $T$. velatus tend to accumulate more $\mathrm{Zn}$ than is present in their microhabitat. It is evident that Ceratozetes mediocris and T. velatus, which were abundant at the dump, must be characterised by an innate or evolved (physiological) resistance to heavy metals that enables them to maintain their populations at highly contaminated sites. Nevertheless, it should be borne in mind that concentrations in the bodies of different individuals of the same species can vary considerably depending on the life stage of the individuals, as was observed in the case of $\mathrm{Zn}$ in T. velatus (Table 2). Time of exposure to heavy metals can affect the amount of a given element accumulated in bodies; however, this is probably not a general rule for oribatids (Skubała and Kafel 2004).

Concentrations of heavy metals are as a rule higher in oribatids collected from the dump's substrate than those from lichen thalli. The strong correlation between the content of metals in oribatids and the corresponding microhabitats was observed only for $\mathrm{Zn}$ (Table 3). This is not surprising, as nutritional metals (e.g. $\mathrm{Zn}$ ) are regulated differently than xenobiotics (e.g. $\mathrm{Pb}$ and $\mathrm{Cd}$ ) in the bodies of oribatid species. Similarly, Skubała and Zaleski (2012) and Skubała et al. (2014) observed that $\mathrm{Zn}$ contents in the bodies of T. velatus were significantly correlated with contents in the corresponding substrate. On the contrary, Skubała and Kafel (2004) found internal $\mathrm{Zn}$ concentrations to be independent of concentrations in forest soil.

According to Siepel (1995), herbofungivorous and fungivorous grazers demonstrate significantly higher body burdens of heavy metals than other mite species in $\mathrm{Pb}$ contaminated environments. It is widely believed that they are more affected by heavy-metal uptake than other feeding guilds of oribatids because they digest fungi cell walls, where large amounts of metals are accumulated (Mowl and Gadd 1984; Trevors et al. 1986). In our study, species utilising different food resources show considerable differences in bioaccumulation of certain metals. However, contrary to expectations, L. lapponicus, Oppiella nova and Oribatula tibialis (fungivorous grazers) have lower body burdens of heavy metals than Ceratozetes mediocris (a panphytophage and herbivore) and T. velatus (an opportunistic herbofungivore). Apart from species-specific differences in metal accumulation, the pattern depends also on the element under consideration, as was reported by Skubała and Kafel (2004), and its bioavailability in the environment (Zaitsev and van Straalen 2001).

\section{Conclusions}

- Thalli of Cladonia lichens represent a less-contaminated microhabitat in heavily contaminated dumps, provide shelter from desiccation, retain humidity and are therefore populated by more numerous and richer oribatid fauna than the surrounding dump's substrate.

- Noticeable and significant differences in oribatid fauna among three Cladonia species are probably due to the morphological characteristics of thalli, production of different secondary metabolites and to some extent varying concentrations of heavy metals in the thalli of particular species.

- High interspecific variation in the concentrations of heavy metals (especially $\mathrm{Zn}$ ) is characteristic of oribatid species. Zinc (as nutrient) is accumulated with unusual efficiency in some oribatid species (Ceratozetes mediocris and $T$. velatus), irrespective of their microhabitats. Lead and cadmium (xenobiotics) are more efficiently regulated by most oribatid species.

- The putative tendency of fungivorous grazers towards greater accumulation of heavy metals in comparison to non-fungivorous ones is not a general rule.

Acknowledgments The authors are grateful to Dr. Alina Kafel (University of Silesia) for making the chemical analyses of the concentration of heavy metals in the body of oribatid mites. The project was financially supported by the National Science Centre (Decision No. DEC-2012/05/ $\mathrm{N} / \mathrm{NZ8} / 00842$ ). 


\section{Appendix}

Table 4 Abundance (indiv. $100 \mathrm{~g}^{-1} \mathrm{DW}$ ) of oribatid species recorded on Cladonia cariosa, Cladonia pyxidata, Cladonia rei thalli and the dump' substrate

\begin{tabular}{|c|c|c|c|c|c|}
\hline Species & Abbr. & C. cariosa & C. pyxidata & C. rei & Substrate \\
\hline Acrogalumna longipluma longipluma (Berlese, 1904) & A long & - & - & - & 0.01 \\
\hline Adoristes (A.) ovatus ovatus (Koch, 1839) & & - & - & 0.11 & - \\
\hline Autogneta (A.) longilamellata longilamellata (Michael, 1885) & A lon & - & - & 0.73 & 0.01 \\
\hline Berniniella (B.) bicarinata (Paoli, 1908) & B bic & - & - & 0.34 & - \\
\hline Berniniella (B.) conjuncta (Strenzke, 1951) & & - & - & 0.10 & - \\
\hline Ceratozetes $(C$.$) mediocris Berlese, 1908$ & $\mathrm{C}$ med & 0.13 & 46.75 & 3.07 & 0.63 \\
\hline Cultroribula bicultrata (Berlese, 1905) & $\mathrm{C}$ bic & - & - & 0.64 & - \\
\hline Dissorhina ornata ornata $\left(\right.$ Oudemans, 1900) ${ }^{\mathrm{C}}$ & & - & - & 0.11 & - \\
\hline Euphthiracarus (E.) cribrarius cribrarius (Berlese, 1904) & & - & 0.22 & - & - \\
\hline Euphthiracarus (E.) monodactylus (Willmann, 1919) & & - & - & 0.11 & - \\
\hline Eupelops tardus (Koch, 1835) & & - & - & 0.11 & - \\
\hline Galumna (G.) lanceata (Oudemans, 1900) & G lan & - & 0.86 & 0.27 & 0.04 \\
\hline Lauroppia falcata falcata (Paoli, 1908) & L fal & - & - & 0.99 & - \\
\hline Licneremaeus licnophorus (Michael, 1882) & & - & - & 0.13 & - \\
\hline Liochthonius (L.) lapponicus (Trägårdh, 1910) ${ }^{\mathrm{C}}$ & L lap & 2.36 & 9.31 & 8.72 & 0.12 \\
\hline Liochthonius (L.) propinquus Niedbała, 1972 & L pro & - & - & 9.04 & - \\
\hline Metabelba (M.) papillipes (Nicolet, 1855) & M pap & - & 2.03 & 0.50 & 0.01 \\
\hline Metabelba (M.) pulverulenta (Koch, 1839) & & - & - & 0.10 & - \\
\hline Micreremus brevipes (Michael, 1888) ${ }^{\mathrm{C}}$ & $\mathrm{N}$ bre & - & 0.22 & 0.13 & - \\
\hline Microppia minus minus (Paoli, 1908) & $\mathrm{M} \min$ & - & - & 0.31 & - \\
\hline Moritzoppia (M.) unicarinata unicarinata (Paoli, 1908) & & - & - & 0.11 & - \\
\hline Oppiella (O.) nova nova (Oudemans, 1902) & O nov & 0.15 & 5.73 & 2.35 & 0.17 \\
\hline Oribatula $\left(\right.$ O.) tibialis tibialis (Nicolet, 1855) ${ }^{\mathrm{C}}$ & O tib & 0.13 & 4.56 & 0.74 & 0.05 \\
\hline Oribatula (Zygoribatula) exilis exilis (Nicolet, 1855) ${ }^{\mathrm{C}}$ & O exi & - & - & 0.23 & - \\
\hline Pantelozetes paolii (Oudemans, 1913) & P pao & - & - & 0.27 & - \\
\hline Pergalumna nervosa nervosa (Berlese, 1914) & P ner & - & 1.30 & 0.22 & 0.04 \\
\hline Pilogalumna crassiclava crassiclava (Berlese, 1914) & P cra & - & - & - & 0.02 \\
\hline Punctoribates (P.) punctum (Koch, 1839) & P pun & - & - & - & 0.19 \\
\hline Quadroppia (Q.) maritalis Lions, 1982 & Q mar & - & - & 0.38 & 0.02 \\
\hline Ramusella (R.) clavipectinata (Michael, 1885) & & - & - & 0.10 & - \\
\hline Rhinoppia obsoleta (Paoli, 1908) & R obs & - & - & 0.14 & 0.02 \\
\hline Sellnickochthonius immaculatus (Forsslund, 1942) & $\mathrm{S}$ imm & 0.81 & 1.05 & 1.09 & 0.03 \\
\hline Subiasella (Lalmoppia) quadrimaculata (Evans, 1952) & & - & - & 0.13 & - \\
\hline Suctobelbella (Flagrosuctobelba) alloenasuta Moritz, 1971 & $\mathrm{~S}$ all & - & 0.54 & 0.10 & 0.08 \\
\hline Suctobelbella (Flagrosuctobelba) baloghi (Forsslund, 1958) & $\mathrm{S}$ bal & - & - & - & 0.02 \\
\hline Suctobelbella (Flagrosuctobelba) nasalis (Forsslund, 1941) & & - & - & 0.10 & - \\
\hline Suctobelbella (S.) acutidens sarekensis (Forsslund, 1941) & S sar & 0.55 & - & 0.11 & 0.02 \\
\hline Suctobelbella (S.) opistodentata (Golosova, 1970) & S opi & - & - & - & 0.02 \\
\hline Suctobelbella $(S$.$) similis (Forsslund, 1941)$ & & - & - & 0.14 & - \\
\hline Suctobelbella $(S$.$) subcornigera subcornigera (Forsslund, 1941)$ & S sub & - & 1.31 & 1.41 & 0.04 \\
\hline Suctobelbella $($ S.) subcornigera vera (Moritz, 1964) & $\mathrm{S}$ ver & - & - & 0.66 & - \\
\hline Suctobelbella (S.) subtrigona (Oudemans, 1900) & S subt & - & 0.56 & - & 0.01 \\
\hline Tectocepheus velatus velatus (Michael, 1880) ${ }^{\mathrm{C}}$ & T vel & 16.18 & 76.33 & 36.99 & 1.57 \\
\hline Trichoribates (T.) novus novus (Sellnick, 1928) & T nov & - & 0.66 & 1.22 & - \\
\hline Trichoribates (Latilamellobates) incisellus incisellus (Kramer, 1897) & $\mathrm{T}$ inc & 0.15 & 0.67 & 0.47 & - \\
\hline
\end{tabular}

C-representative of group C (Seyd and Seaward 1984) 
Open Access This article is distributed under the terms of the Creative Commons Attribution 4.0 International License (http:// creativecommons.org/licenses/by/4.0/), which permits unrestricted use, distribution, and reproduction in any medium, provided you give appropriate credit to the original author(s) and the source, provide a link to the Creative Commons license, and indicate if changes were made.

\section{References}

Alberti G, Seniczak A, Seniczak S (2003) The digestive system and fat body of an early-derivative oribatid mites, Archegozetes longisetosus Aoki (Acari: Oribatida, Trhypochthoniidae). Acarologia 43:151-222

Asplund J, Gauslaa Y (2007) Content of secondary compounds depends on thallus size in the foliose lichen Lobaria pulmonaria. Lichenologists 39:273-278

Asplund J, Gauslaa Y (2008) Mollusc grazing limits growth and early development of the old forest lichen Lobaria pulmonaria in broadleaved deciduous forests. Oecologia 155:93-99

Behan-Pelletier VM, Walter DE (2000) Biodiversity of oribatid mites (Acari: Oribatida) in tree canopies and litter. In: Coleman DC, Hendrix PF (eds) Invertebrates as webmasters in ecosystems. CAB International, Wallingford, pp 187-202

Bengtsson G, Hedlund K, Rundgren S (1994) Food- and densitydependent dispersal: evidence from a soil collembolan. J Anim Ecol 63:513-520

Colloff MJ (1988) Species associations of oribatid mites in lichens on the Island of Ailsa Craig, Firth of Clyde (Acari: Cryptostigmata). J Nat Hist 22:1111-1119

Creamer RE, Rimmer DL, Black HIJ (2008) Do elevated soil concentrations of metals affect the diversity and activity of soil invertebrates in the long term? Soil Use Manag 24:37-46

Cuny D, Denayer FO, de Foucault B, Schumacker R, Colein P, van Haluwyn C (2004) Patterns of metal soil contamination and changes in terrestrial cryptogamic communities. Environ Pollut 129:289-297

Dolnik C, Beck A, Zarabaska D (2010) Distinction of Cladonia rei and C. subulata based on molecular, chemical and morphological characteristics. Lichenologists 42:373-386

El-Sharabasy HM, Ibrahim A (2010) Communities of oribatid mites and heavy metal accumulation in oribatid species in agricultural soils in Egypt impacted by waste water. Plant Prot Sci 46:159-170

Erdmann G, Floren A, Linsenmair KE, Scheu S, Maraun M (2006) Little effect of forest age on oribatid mites on the bark of trees. Pedobiologia 50:433-441

Erdmann G, Otte V, Langel R, Scheu S, Maraun M (2007) The trophic structure of bark-living oribatid mite communities analysed with stable isotopes $\left({ }^{15} \mathrm{~N},{ }^{13} \mathrm{C}\right)$ indicates strong niche differentiation. Exp Appl Acarol 41:1-10

Fischer BM, Schatz H, Maraun M (2010) Community structure, trophic position and reproductive mode of soil and bark-living oribatid mites in an alpine grassland ecosystem. Exp Appl Acarol 52:221237

Fröberg L, Solhøy T, Baur A, Baur B (2003) Lichen specificity of oribatid mites (Acari: Oribatida) on limestone walls in the Great Alvar of Oland, Sweden. Entomol Tidskrift 124:77-82

Gauslaa Y (2005) Lichen palatability depends on investments in herbivore defence. Oecologia 143:94-105

Gerson U, Seaward MRD (1977) Lichen-invertebrate associations. In: Seaward MRD (ed) Lichen ecology. Academic Press, London, pp 69-119
Gjelstrup P, Søchting U (1979) Cryptostigmatid mites (Acarina) associated with Ramalina siliquosa (Lichenes) on Bornholm in the Baltic. Pedobiologia 19:237-245

Grime JP (1979) Plant strategies and vegetation processes. Wiley, Chichester

Hesbacher S, Baur B, Baur A, Proksch P (1995) Sequestration of lichen compounds by three species of terrestrial snail. J Chem Ecol 21: 233-246

Huneck S (1999) The significance of lichens and their metabolites. Naturwissenschaften 86:559-570

Huneck S, Yoshimura Y (1996) Identification of lichen substances. Springer Verlag, Berlin

James PW (2009) Cladonia P. Browne (1756). In: Smith CW, Aptroot A, Coppins BJ, Fletcher A, Gilbert OL, James PW, Wolseley PA (eds) The lichens of Great Britain and Ireland. The British Lichen Society, London, pp 309-338

Janssen MPM, Hogervorst RF (1993) Metal accumulation in soil arthropods in relation to micro-nutrients. Environ Pollut 79:181-189

Kabata-Pendias A, Pendias H (2001) Trace element in soils and plants, 3rd edn. CRC Press, Boca Raton

Lawrey JD (1987) Nutritional ecology of lichen/moss arthropods. In: Slansky F Jr, Rodriguez JG (eds) Nutritional ecology of insects, mites, spiders and related invertebrates. Wiley, New York, pp 209 233

Lebrun P, Van Straalen NM (1995) Oribatid mites: prospects of their use in ecotoxicology. Exp Appl Acarol 19:361-380

Ludwig M, Kratzmann M, Alberti G (1992) The influence of some heavy metals on Steganacarus magnus (Acari, Oribatida). Z Angew Zool 79:455-467

Maraun M, Scheu S (2000) The structure of oribatid mite community (Acari, Oribatida), mechanisms and implication for future research. Ecography 23:374-383

Maraun M, Salamon JA, Schneider K, Schaefer M, Scheu S (2003) Oribatid mite and collembola diversity, density and community structure in a moder beech forest (Fagus sylvatica): effects of mechanical perturbations. Soil Biol Biochem 35:1387-1394

Materna J (2000) Oribatid communities (Acari: Oribatida) inhabiting saxicolous mosses and lichens in the Krkonose Mts. (Czech Republic). Pedobiologia 44:40-62

Molnár K, Farkas E (2010) Current results on biological activities of lichen secondary metabolites: a review. Z Naturforsch 65C:157-173

Mowl JL, Gadd GM (1984) Cadmium uptake by Aureobasidium pullulans. J Gen Microbiol 130:279-284

Nimis PL, Skert N (2006) Lichen chemistry and selective grazing by the Coleopteran Lasioderma serricorne. Environ Exp Bot 55:175-182

Orange A, James PW, White FJ (2001) Microchemical methods for the identification of lichens. British Lichen Society, London

Osyczka P, Rola K (2013a) Cladonia lichens as the most effective and essential pioneers in strongly contaminated slag dumps. Cent Eur J Biol 8:876-887

Osyczka P, Rola K (2013b) Response of the lichen Cladonia rei Schaer. to strong heavy metal contamination of the substrate. Environ Sci Pollut R 20:5076-5084

Osyczka P, Rola K, Lenart-Boroń A, Boroń P (2014) High intraspecific variation in the pioneer lichen Cladonia rei colonising slag dumps. Cent Eur J Biol 9:876-887

Pöykkö H, Hyvärinen M, Bačkor M (2005) Removal of lichen secondary metabolites affects food choice and survival of lichenivorous moth larvae. Ecology 86:2623-2632

Prinzing A, Wirtz H-P (1997) The epiphytic lichen, Evernia prunastri L. as a habitat for arthropods: shelter from desiccation, food-limitation and indirect mutualism. In: Stork NE, Adis J, Didham RK (eds) Canopy arthropods. Chapman \& Hall, London, pp 477-494

Purvis OW, Halls C (1996) A review of lichens in metal-enriched environments. Lichenologist 28:571-601 
Rainbow PS (1988) The significance of trace metal concentrations in decapods. In: Fincham AA, Rainbow PS (eds) Aspects of decapod crustacean biology, 59. Zool Soc Lond Zool Symp. pp 291-313

Reutimann P, Scheidegger C (1987) Importance of lichen secondary products in food choice of two oribatid mites (Acari) in alpine meadow ecosystem. J Chem Ecol 13:363-369

Rola K, Osyczka P (2014) Cryptogamic community structure as a bioindicator of soil condition along a pollution gradient. Environ Monit Assess 186:5897-5910

Rola K, Osyczka P, Nobis M (2014) Cryptogamic communities dominated by the lichen Cladonia rei-a case study of Polish post-smelting dumps in a worldwide context. Herzogia 27:121-135

Rola K, Osyczka P, Nobis M, Drozd P (2015) How do soil factors determine vegetation structure and species richness in post-smelting dumps? Ecol Eng 75:332-342

Root HT, McGee GG, Norton RA (2007) Arboreal mite communities on epiphytic lichens of the Adirondack Mountains of New York. Northeast Nat 14:425-438

Roth M (1992) Metals in invertebrate animals of a forest ecosystem. In: Adriano DC (ed) Biogeochemistry of trace metals. Lewis, Boca Raton, pp 299-328

Roth M (1993) Investigations on lead in the soil invertebrates of a forest ecosystem. Pedobiologia 37:270-279

Seyd EL, Seaward MRD (1984) The association of orbatid mites with lichens. Zool J Linn Soc-Lond 80:369-420

Siepel H (1995) Are some mites more ecologically exposed to pollution with lead than others? Exp Appl Acarol 19:391-398

Skubała K (2011) Vascular flora of sites contaminated with heavy metals on the example of two post-industrial spoil heaps connected with manufacturing of zinc and lead products in Upper Silesia. Arch Environ Prot 37:55-74

Skubała P, Kafel A (2004) Oribatid mite communities and metal bioaccumulation in oribatid species (Acari, Oribatida) along the heavy metal gradient in forest ecosystems. Environ Pollut 132:51-60

Skubała P, Zaleski T (2012) Heavy metal sensitivity and bioconcentration in oribatid mites (Acari, Oribatida). Gradient study in meadow ecosystems. Sci Total Environ 414:364-372

Skubała P, Rola K, Osyczka P, Kafel A (2014) Oribatid mite communities on lichens in heavily contaminated post-smelting dumps. Arch Environ Contam Toxicol 67:578-592

Slansky F Jr (1979) Effects of the lichen chemicals atranorin and vulpinic acid upon feeding and growth of larvae of the yellow-striped armyworm, Spodoptera ornithogallii. Environ Entomol 8:865-868
Smrž J, Kocourková J (1999) Mite communities of two epiphytic lichen species (Hypogymnia physodes and Parmelia sulcata) in the Czech Republic. Pedobiologia 43:385-390

Stubbs CS (1995) Dispersal of soredia by the oribatid mite, Humerobates arborea. Mycologia 87:454-458

Subias LS (2004) Listado sistemático, sinonímico y biogeográfico de los Ácaros Oribátidos (Acariformes, Oribatida) del mundo (17582002). Graellsia 60 (in Spanish with English summary). Updated in February 2014. Available from http://www.ucm.es/info/zoo/ Artropodos/Catalogo.pdf

Taylor MG, Simkiss K (1984) Inorganic deposits in invertebrate tissues. Environ Chem 3:102-138

ter Braak CJF, Šmilauer P (2002) CANOCO Reference manual and CanoDraw for Windows User's guide. Software for Canonical Community Ordination (version 4.5). Microcomputer Power, Ithaca

Tordoff GM, Baker AJ, Willis AJ (2000) Current approaches to the revegetation and reclamation of metalliferous mine wastes. Chemosphere 41:219-228

Tranvik L, Eijsackers H (1989) On the advantages of Folsomia fimetarioides over Isotomiella minor (Collembola) in a metal polluted soil. Oecologia 80:195-200

Trevors JT, Stratton GW, Gadd GM (1986) Cadmium transport, resistance and toxicity in bacteria, algae and fungi. Can J Microbiol 32: $447-464$

Tyszka R, Kierczak J, Pietranik A, Ettler V, Mihaljevič M (2014) Extensive weathering of zinc smelting slag in a heap in Upper Silesia (Poland): potential environmental risks posed by mechanical disturbance of slag deposits. Appl Geochem 40:70-81

Van Straalen NM, Van Wensem J (1986) Heavy metal content of forest litter arthropods as related to body-size and trophic level. Environ Pollut 42:209-221

Weigmann G (2006) Hornmilben (Oribatida). Die Tierwelt Deutschlands, 76. Teil. Goecke and Evers, Keltern (in German).

Zaitsev AS (1999) Metal accumulation by oribatid mites in the surroundings of the Kosogorsky metallurgical plant. In: Butovsky RO, Van Straalen NM (eds) Pollution-induced changes in soil invertebrate food-webs. Report No. D99017. Vrije Universiteit, Amsterdam, pp $51-70$

Zaitsev AS, Van Straalen NM (2001) Species diversity and metal accumulation in oribatid mites (Acari, Oribatida) of forests affected by a metallurgical plant. Pedobiologia 45:467-479 